\title{
PENGARUH KETINGGIAN AIR YANG BERBEDA TERHADAP PERTUMBUHAN DAN KELANGSUNGAN HIDUP BELUT (Monopterus albus)
}

\section{THE EFFECT OF DIFFERENT WATER LEVEL ON THE GROWHT AND SURVIVAL OF EELS (Monopterus albus)}

\author{
Atiasyifa Kusuma Ningtyas ${ }^{1 *}$, M. Junaidi ${ }^{1)}$, Muhammad Marzuki ${ }^{1)}$ \\ ${ }^{1)}$ Program Studi Budidaya Perairan, Universitas Mataram \\ Jl. Pendidikan No, 37 Mataram, NTB
}

\begin{abstract}
Abstrak
Penelitian ini bertujuan untuk mengetahui pengaruh ketinggian air terhadap pertumbuhan dan kelangsungan hidup belut sawah tanpa substrat. Belut yang digunakan memiliki bobot rata-rata $19,38 \pm 1,30$ gram dan panjang rata-rata $6,78 \pm 1,01 \mathrm{~cm}$ yang dipelihara selama 70 hari masa pemeliharaan dalam dua ketinggian air yang berbeda, yaitu (A) $3 \mathrm{~cm}$ dan (B) $5 \mathrm{~cm}$. Berdasarkan hasil Uji $\mathrm{t}$ bebas menunjukkan perlakuan $\mathrm{B}$ memberikan pertumbuhan panjang mutlak yang lebih tinggi dengan nilai $2,24 \mathrm{~cm}$ serta kelangsungan hidup sekitar $80 \%$. Namun tidak ada perbedaan nyata $(\mathrm{P}>0,05)$ pada pertumbuhan bobot mutlak $(2,47-2,83$ gram) dan laju pertumbuhan bobot spesifik $(0,45-050 \%)$.
\end{abstract}

Kata kunci : belut sawah, ketinggian air, kelangsungan hidup, pertumbuhan

\begin{abstract}
The objective of this research was to address the effect of water level on the growth and the survival rate of rice eel without using a substrate. The eel which was used in this study had an average weight of 19.38 \pm 1.30 gram and an average length of $6.78 \pm 1.01 \mathrm{~cm}$ which was kept for 70 days in two different water levels; that is, (A) $3 \mathrm{~cm}$ and (B) $5 \mathrm{~cm}$. The T-test shows that the treatment B produced total length of $2.24 \mathrm{~cm}$ and the survival rate around $80 \%$. There were no differences $(\mathrm{P}>0.05)$ in weight gain, 2.47 to 2.83 gram, and spesific weight growht rate, $0.45-050 \%$.
\end{abstract}

Keywords : eels, water level, survival rate, growth

\section{Pendahuluan}

Belut merupakan salah satu komoditas perikanan yang cukup banyak digemari masyarakat karena rasanya yang gurih dan kandungan proteinnyatinggi. Kandungan protein yang terkandung dalam belut berkisar sekitar 18,4 gram per 100 gram (Saparinto, 2010). Oleh karena itu, potensi pasar bagi belut ini sangatlah terbuka lebar dan sangat menjanjikan. Permintaan pasar akan belut tidak hanya berasal dari dalam negeri namun juga luar negeri. Pasar ekspor belut diperkirakan dunia membutuhkan 230 ribu ton/tahun belut beku dan dingin (Umar, 2013). Data dari Badan Pusat Statistik (2013) mengungkapkan produksi belut terutama pada Provinsi Nusa Tenggara Barat baru mampu email korespondensi : Atiasyifa.k@gmail.com memenuhi 2,85 ton dengan harga $\mathrm{Rp}$ $72.527 / \mathrm{kg}$ belut. Selain itu, kebutuhan akan belut masih bergantung pada penangkapan dari alam. Semakin meningkatnya permintaan pasar tehadap belut tentu tidak hanya bisa dilakukan dengan mengandalkan penangkapan dari alam karena dapat menimbulkan dampak negatif pada ketersediaan belut dan dapat mengakibatkan produksi benih belut di alam menjadi menurun.

Usaha budidaya belut sudah mulai dilakukan namun belum se-intensif budidaya jenis ikan lainnya. Media pemeliharaan yang umum digunakan dalam budidaya belut adalah substrat lumpur. Penggunaan substrat lumpur ditunjukkan untuk mengikuti habitat asli dari belut. Namun, budidaya dengan substrat lumpur ini memiliki beberapa kelemahan, 
yaitu persiapan media yang membutuhkan waktu yang cukup lama dan memerlukan campuran bahan lainnya. Solusi untuk permasalahan tersebut adalah penggunaan media air jernih sebagai media pemeliharaan. Budidaya belut menggunakan media air jernih akan membuat belut lebih mudah dikontrol pertumbuhan dan kelangsungan hidupnya, memudahkan pengamatan dalam pemberian pakan, dan mempermudah proses pemanenan (Taufik dan Saparinto, 2008).

Penggunaan media air dalam budidaya belut perlu memperhatikan kualitas air dan tinggi permukaan air. Belut termasuk hewan yang malas bergerak dan mempunyai kebiasaan mengambil oksigen langsung ke udara. Ketinggian air yang tinggi dapat menyebabkan jarak ke permukaan semakin besar dalam belut mengambil oksigen ke udara (Witjaksono, 2009). Semakin besar jarak yang ditempuh dalam mengambil oksigen ke permukaan dapat mengakibatkan banyaknya energi yang terkuras untuk bergerak. Penggunaan ketinggian air yang rendah juga memberikan beberapa keuntungan, yaitu volume air yang digunakan menjadi berkurang dan ruang gerak dari benih belut menjadi makin terbatas. Namun demikan, penggunaan ketinggian air yang rendah dapa tmeningkatkan konsentrasi amoniak di dalam air sehingga selanjutnya dapat mempengaruhi pertumbuhan dan kelangsungan hidup dari belut.

\section{Metode Penelitian}

Penelitian ini dilaksanakan selama 70 hari terhitung dari 1 Desember 2017 sampai dengan 10 Februari 2018 bertempat di Laboratorium Budidaya Perairan Program Studi Budidaya Perairan Universitas Mataram.

Penelitian ini dilakukan secara eksperimental menggunakan $\mathrm{Uji} \mathrm{t}$ bebas dengan 2 perlakuan dan 10 ulangan sehingga ada 20 unit percobaan. Perlakuan yang dilakukan sebagai berikut: A (Ketinggian air 3 $\mathrm{cm}$ ) dan B (Ketinggian air $5 \mathrm{~cm}$ ).

\section{Persiapan Wadah dan Benih}

Wadah yang digunakan untuk tempat pemeliharaan benihberupa akuarium ukuran 30x30x30 $\mathrm{cm}^{3}$ sebanyak 20 buah. Sebelum digunakan akuarium terlebih dahulu dibersihkan dengan air bersih, kemudian dikeringkan. Akuarium kemudian disusun teratur dan diberikan plastik hitam agar benih tidak stress serta tanda nama perlakuan pada tiap akuarium. Setelah itu, akuarium diisi air dengan ketinggian yang telah ditentukan, yaitu setinggi $3 \mathrm{~cm}$ dan $5 \mathrm{~cm}$. Sistem yang digunakan dalam pemeliharaan benih adalah sistem air mengalir dimana air dimasukkan pada botol yang diletakkan di atas tiap unit perlakuan, air dialirkan dari botol menggunakan selanginfusan yang digunakan untuk mengatur volume air yang masuk ke dalam wadah unit perlakuan. Air dari dalam unit perlakuan akan dikeluarkan dengan menggunakan selang infusanlagi agar volume air yang masukdengan yang keluarsamasecara gravitasi menuju talang air sampai pada bak penampungan air.

Sebelum perlakuan, belut yang baru datang dari tempat pemesanan biasanya akan mengalami stres ketika langsung diletakkan pada media air jernih sehingga tidak dapat langsung dimasukkan ke wadah unit perlakuan. Setelah bibit belut disortir dari yang telah mati, bibit yang masih hidup akan dikarantina sekaligus sebagai proses adaptasinyaselama 4 minggu. Belutditempatkandalambak karantina yang diisidengan media air belumpur. Selanjutnya, komposisi lumpur dikurangi sedikit demi sedikit setiap harinya sehingga semakin lama media lumpur akan habis dan akan menjadi media air keseluruhan. Selama 1-2 hari, bibit belut tidak diberi pakan terlebih dahulu. Setelah 2 hari kemudian, bibit belut baru dilakukan pemberian pakan berupa cacing sutera sampai bibit belut benar-benar sehat. Selama masa karantina belut diamati sehingga diketahui jika ada belut yang sakit. Bibit belut yang sakit akan diambil dan dipisahkan dengan bibit yang sehat. Tanda bibit belut yang sakit biasanya akan lamban, mendongakan kepalanya keatas (permukaan air), dan tidak nafsu makan.

\section{Pemeliharaan Belut}

Benih belut (Monopterus albus) yang digunakan dalam penelitian ini memiliki panjang rata-rata $19,38 \pm 1,30 \mathrm{~cm}$ dan bobot rata-rata $6,78 \pm 1,01$ gram yang berasal dari unit pembenihan belut di Jawa. Belut yang sudah diadaptasikan sebelumnya dipindahkan pada wadah-wadah yang telah disediakan. Benih ditebar sebanyak 1 ekor per akuarium menggunakan system acak (lotre). Selama pemeliharaan belut diberi pakan cacing sutera 
sehari sekali yaitu pada saat sore menjelang malam hari. Metode pemberian pakan secara ad libitum atau pakan selalu tersediadi dalam wadah pemeliharaan minimal 5\% dari berat badan.

\section{Pengumpulan dan Analisa data}

Pengukuran pertumbuhan bobot dan panjang serta kelangsungan hidup ikan uji dilakukan pada awal dan akhir pemeliharaan. Seluruh ikan diambil untuk dilakukan pengamatan. Pengambilan sampel air dilakukan setiap 7 hari sekali selama masa pemeliharaan. Sampel ini digunakan untuk pengukuran kualitas air yang dilakukan di Laboratorium Budidaya Perairan Program Studi Budidaya Perairan Universitas Mataram.

Parameter yang diuji secara statistik adalah tingkat kelangsungan hidup $(\mathrm{SR})=\mathrm{Nt} / \mathrm{No} \mathrm{x}$ $100 \%$; pertumbuhan panjang mutlak $(\mathrm{L})=\mathrm{Lt}-$ Lo; pertumbuhan bobot mutlak $(\mathrm{W})=\mathrm{Wt}-$ Wo dan; laju pertumbuhan bobot spesifik $($ LPS $)=\ln \mathrm{Wt}-\ln \mathrm{Wo} / \mathrm{t} \times 100 \%$. Nt $=$ jumlah ikan yang hidup pada akhir pemeliharaan; No $=$ jumlah ikan pada akhir pemeliharaan; $\mathrm{Lt}=$ panjang rata-rata akhir; Lo = panjang rata-rata awal; $\mathrm{Wt}=$ bobot rata-rata ikan pada akhir pemeliharaan; $\mathrm{Wo}=$ bobot rata-rata ikan pada awal pemeliharaan. Parameter kualitas air yang diukur terdiri atas suhu, oksigen terlarut, $\mathrm{pH}$, dan amonia. Nilai pertumbuhan panjang mutlak, pertumbuhan bobot mutlak, dan laju pertumbuhan bobot spesifik diolah menggunakan Uji t bebas. Data kualitas air yang diperoleh dianalisis secara deskriptif dengan penyajian tabel..

\section{Hasil}

\section{Pertumbuhan dan Kelangsungan Hidup}

Data hasil pengaruh ketinggian air terhadap pertumbuhan dan kelulushidupan belut sawah selama penelitian dapat dilihat pada Tabel 1 . Berdasarkan hasil Uji t bebas menunjukkan bahwa perbedaan ketinggian air berpengaruh $(\mathrm{p}<0,05)$ terhadap pertumbuhan panjang mutlak, tetapi tidak berpengaruh $(\mathrm{p}>0,05)$ terhadap pertumbuhan bobot mutlak dan laju pertumbuhan spesifik belut. Pertumbuhan panjang mutlak terbaik terdapat pada perlakuan ketinggian air $5 \mathrm{~cm}$ yaitu $2,30 \mathrm{~cm}$.
Tabel 1. Hasil Data Pertumbuhan Panjang dan Berat, Laju Pertumbuhan Spesifik serta Kelangsungan Hidup

\begin{tabular}{lcc}
\hline \multirow{2}{*}{ Parameter } & \multicolumn{2}{c}{ Ketinggian Air } \\
\cline { 2 - 3 } & $3 \mathrm{~cm}$ & $5 \mathrm{~cm}$ \\
\hline $\begin{array}{l}\text { Pertumbuhan } \\
\text { Panjang Mutlak } \\
(\mathrm{cm})\end{array}$ & $1,18 \pm 0,33^{\mathrm{a}}$ & $2,24 \pm 0,33^{\mathrm{b}}$ \\
$\begin{array}{l}\text { Pertumbuhan } \\
\text { Bobot Mutlak } \\
\text { (g) }\end{array}$ & $2,83 \pm 0,025^{\mathrm{a}}$ & $2,47 \pm 0,64^{\mathrm{a}}$ \\
$\begin{array}{l}\text { Laju } \\
\text { Pertumbuhan }\end{array}$ & $0,50 \pm 0,03^{\mathrm{a}}$ & $0,45 \pm 0,14^{\mathrm{a}}$ \\
$\begin{array}{l}\text { BobotSpesifik } \\
(\%)\end{array}$ & \\
$\begin{array}{l}\text { Kelangsungan } \\
\text { Hidup (\%) }\end{array}$ & $40,0 \pm 51,64$ & $80,0 \pm 0,71$ \\
\hline $\begin{array}{l}\text { Ket. Superskrip yang berbeda pada kolom yang sama } \\
\text { menunjukkan terdapat perbedaan (p<0,05) }\end{array}$
\end{tabular}

\section{Data Kualitas Air}

Kondisi lingkungan merupakan salah satu faktor pendukung bagi pertumbuhan dan kelangsungan hidup belut. Pengukuran kualitas air yang diperoleh meliputi suhu, PH, DO, dan $\mathrm{NH}_{3}$. Kualitas air selama penelitian memperlihatkan bahwa suhu pada perlakuan 5 cm, pH, dan $\mathrm{NH}_{3}$ masih dalam kisaran toleransi. Sedangkan oksigen terlarut dan suhu pada perlakuan $3 \mathrm{~cm}$ cenderung berada di luar kisaran toleransi. Data pengukuran kualitas air disajikan pada Tabel 2.

Tabel 2. Hasil Pengukuran Kualitas Air

\begin{tabular}{lccc}
\hline \multirow{2}{*}{ Parameter } & \multicolumn{2}{c}{ Ketinggian Air } & \multirow{2}{*}{ Kisaran } \\
\cline { 2 - 3 } & $3 \mathrm{~cm}$ & $5 \mathrm{~cm}$ & Optimal \\
\hline DO $(\mathrm{mg} / \mathrm{l})$ & $3-3,32$ & $3,05-3,62$ & $3-5(\mathrm{a})$ \\
$\mathrm{Suhu}\left({ }^{\circ} \mathrm{C}\right)$ & $27,2-27,8$ & $27,6-28,0$ & $25-28(\mathrm{~b})$ \\
$\mathrm{pH}$ & $6,6-7,0$ & $6,6-6,8$ & $<7(\mathrm{~b})$ \\
$\mathrm{NH}_{3}$ & $0,09-0,60$ & $0,10-0,39$ & $<1(\mathrm{c})$ \\
\hline
\end{tabular}

Ket : (a) = Kordi (2014), (b) = Junariyata dan Dewi (2016), dan (c) = Saparinto (2010)

\section{Pembahasan}

Pertumbuhan adalah pertambahan ukuran baik panjang maupun berat dalam kurun waktu tertentu. Belut sawah yang dipelihara selama 70 hari dapat tumbuh pada ketinggian air $3 \mathrm{~cm}$ dan $5 \mathrm{~cm}$ serta mengalami peningkatan pertumbuhan panjang mutlak, bobot mutlak, maupun laju pertumbuhan spesifiknya. Hal ini menunjukkan bahwa belut dapat memanfaatkan pakan sebagai sumber energi. 
Pertumbuhan panjang mutlak terbaik terjadi pada perlakuan ketinggian air $5 \mathrm{~cm}$ yang kemudian diikuti dengan perlakuan ketinggian air $3 \mathrm{~cm}$. Tingginya nilai pertumbuhan panjang mutlak pada ketinggian air $5 \mathrm{~cm}$ yang didapatkan ini sejalan dengan pernyataan Witjaksono (2009) bahwa permukaan air yang tinggi akan berpengaruh pada pertumbuhan panjang mutlak ikan, karena semakin tinggi air dalam wadah pemeliharaan, semakin besar pula jarak ke permukaan air untuk mengambil oksigen dan memanfaatkan pakan. Saparinto (2010) juga menyatakan bahwa semakin tinggi permukaan air maka belut akan lebih sering bergerak yang mengakibatkan bentuk badannya menjadi lebih panjang dan kurus dibandingkan dengan permukaan air yang rendah, belut akan sedikit bergerak sehingga bentuk badannya akan menjadi gemuk dan besar yang mana ketinggian air yang baik untuk pertumbuhan belut sekitar $5 \mathrm{~cm}$.

Pertumbuhan bobot mutlak dan laju pertumbuhan bobot spesifik pada belut menunjukkan hasil yang tidak berbeda nyata antar perlakuan diduga karena padat tebar belut tiap perlakuan hanya 1 ekor sehingga belut mendapatkan ruang gerak yang cukup dalam menunjang pertumbuhannya yang mengakibatkan tidak adanya persaingan atau perebutan ruang gerak maupun pakan pada belut.

Hasil laju pertumbuhan bobotspesifik yang diperoleh dari penelitian ini $(0,45-0,50 \%)$ lebih besar dari pertumbuhan pada penelitian Santoso (2014), yaitu 0,40-0,42\%. Hal ini terjadi diduga karena perbedaan jenis pakan dan kandungan nutrisi yang diberikan pada penelitian ini. Mashuri et al., (2012) menyatakan bahwa persentase pakan yang akan digunakan untuk pertambahan bobot ikan yang dipelihara berkaitan erat dengan jenis pakan yang dimakan. Kandungan protein pada pakan cacing sutera yang diberikan lebih dapat memenuhi kebutuhan protein dalam tubuh belut sawah. Terpenuhinya kebutuhan protein pada belut sawah akan mempercepat laju pertumbuhan, karena protein merupakan bahan pembentuk sel dan berperan penting dalam produksi enzim (Steffens, 1989 dalam Mulyana, 2004).

Salah satu parameter keberhasilan dari suatu kegiatan budidaya adalah kelangsungan hidup. Pada perlakuan ketinggian air $3 \mathrm{~cm}$ terlihat memiliki tingkat kelangsungan hidup sekitar $40 \%$ dan pada perlakuan ketinggian air $5 \mathrm{~cm}$ sekitar $80 \%$. Ketinggian air erat kaitannya dengan volume air. Semakin tinggi ketinggian air, maka volume air juga akan semakin besar. Volume air diduga dapatmempengaruhi konsentrasi amoniak di dalam air.Semakin besar volume air maka konsentrasi amoniak akan lebih kecil sehingga menyebabkan kelangsungan hidup pada ketinggian air $5 \mathrm{~cm}$ lebih tinggi dibandingkan pada ketinggian air $3 \mathrm{~cm}$. Timur (2001) juga menyatakan bahwa pada tingkat ketinggian air yang rendah pengenceran bahan-bahan organic akan lebih rendah bila dibandingkan dengan tingkat ketinggian air yang lebih dalam sehingga berpengaruh terhadap kandungan bahan organik yang terdapat dalam air.

Berdasarkan hasil pengamatan kualitas air yang telah dilakukan didapatkan nilai kualiatas air yang masih dalam kisaran optimal bagi pertumbuhan dan kelangsungan hidup belut (Tabel 7). Hasil kualitas air ini didukung oleh Kordi (2014), kandungan oksigen terlarut yang baik berkisar 3-5 mg/l. Suhu yang baik berkisar antara $25-28^{\circ} \mathrm{C}$ (Junariyata dan Dewi ,2016), serta $\mathrm{pH}$ dan amonia masing-masing yaitu $<7$ dan <1 (Junariyata dan Dewi, 2016 serta Saparinto, 2010).

\section{Kesimpulan}

Ketinggian air media pemeliharaan $5 \mathrm{~cm}$ menunjukkan pertumbuhan panjang belut dan kelangsungan hidup yang lebih tinggi dibandingkan dengan belut pada ketinggian air $3 \mathrm{~cm}$, meski pertumbuhan berat menunjukkan hasil yang tidak berbeda

\section{Daftar Pustaka}

Badan Pusat Statistik. (2013). Produksi dan Nilai Produksi Perikanan Darat Menurut Jenis Ikan. Diakses dari https://ntb.bps.go.id pada tanggal 30 Agustus 2017.

Kordi, M. G. H. (2014). Budidaya Belut di Media Air secara Organik. Yogyakarta: Lily Publisher.

Mashuri, Sumarjan dan Abidin Z. (2012). Pengarih Jenis Pakan yang Berbeda terhadap Pertumbuhan Belut Sawah (Monopterus albus Zuieuw). Jurnal Perikanan Unram, 1 (1): 1-7.

Mulyana, T. Z. (2004). Efesiensi Pemberian beberapa Pakan untuk Ikan Sidat (Anguilla 
sp.) yang Dipelihara dalam Sistem Resirkulasi. Jurusan Budidaya Perairan. Institut Pertanian Bogor. Bogor.

Santoso, R. (2014). Penambahan Atraktan yang Berbeda dalam Pakan Buatan Pasta terhadap Pertumbuhandan Feed Convertion Ratio Belut (Monopterus albus) dengan Sistem Resirkulasi. Fakultas Perikanan dan Kelautan. Universitas Airlangga. Surabaya.

Saparinto, C. (2010). Panduan Lengkap Belut. Jakarta: Penebar Swadaya.

Taufik, A dan Saparinto, C. (2008). Usaha Pembesaran Belut. Jakarta: Penebar Swadaya.

Timur, R. (2001). Pengaruh Tingkat Ketinggian Air Media Budidaya terhadap Pertumbuhan dan Kelangsungan Hidup Udang Windu (Penaeus monodon
Fabricius). Jurusan Budidaya Perairan. Institut Pertanian Bogor. Bogor.

Umar, B. (2013). Induksi Pematangan Gonad Belut Sawah Monopterus albus menggunakan Kombinasi Hormon Gonadotropin dan Antidopamin 10 ppm. Jurusan Budidaya Perairan. Institut Pertanian Bogor. Bogor.

Witjaksono, A. (2009). Kinerja Produksi Pendederan Lele Sangkuriang (Clarias sp) Melalui Penerapan Teknologi Ketinggian Media Air $15 \mathrm{~cm}, 20 \mathrm{~cm}, 25 \mathrm{~cm}$, $30 \mathrm{~cm}$.Program Studi Teknologi Dan Manajemen Akuakultur Fakultas Perikanan Dan Ilmu Kelautan Institut Pertanian Bogor. Bogor. 